\title{
Limitations of Chloroaluminate Ionic Liquid Anolytes for Aluminum-Graphite Dual-Ion Batteries
}

Cite This: ACS Energy Lett. 2020, 5, 545-549

Read Online

\begin{tabular}{|c|c|c|}
\hline ¿CESS I & Llll Metrics \& More & 回 Article Recommendations \\
\hline
\end{tabular}

$\Delta$ t present, the replacement of fossil fuels by alternative $\mathrm{CO}_{2}$-emission-free energy sources, such as solar and wind, is substantially hindered by the lack of low-cost and large-scale energy storage technologies. Although lithiumion batteries (LIBs) represent the most mature and widely deployed electrochemical energy storage technology for mobility and portable electronics, the uneven worldwide distribution of known lithium reserves and the high production costs greatly reduce the economic appeal of LIBs for large-scale stationary storage. ${ }^{1-5}$ In this regard, inexpensive $\mathrm{Al}$-graphite dual-ion batteries (AGDIBs) have attracted great attention over the past few years. ${ }^{6-26}$ With energy densities of $30-70 \mathrm{Wh} \mathrm{kg}^{-1}$, AGDIBs are suitable for stationary storage. ${ }^{27-30}$ The constituents of AGDIBs include highly abundant elements ( $\mathrm{H}, \mathrm{O}, \mathrm{N}, \mathrm{C}$, and $\mathrm{Al}$ ) and are easy to manufacture. While recent research efforts on AGDIBs have been mainly focused on testing various graphite cathodes, further progress of this technology is inherently limited by the low charge storage capacity of the chloroaluminate ionic liquids used as anolytes (often but incorrectly called electrolytes). In this Viewpoint, we discuss the critical interplay between the capacity of the anolyte and the energy density of AGDIBs along with their measurements at different current densities.

The basic configuration of an AGDIB contains a graphite cathode, $\mathrm{AlCl}_{3}$-EMIMCl (1-ethyl-3-methylimidazolium chloride) ionic liquid anolyte, and metallic aluminum current collector, as demonstrated in Figure 1a. AGDIBs operate as an electrochemical energy storage system by employing the reversible intercalation of $\mathrm{AlCl}_{4}{ }^{-}$anion species into the positive graphite electrode upon charging (i.e., the oxidation of the graphite network). Concurrently, the aluminum electroplating reaction takes place on the negative side of AGDIBs. The working principle of AGDIBs can be represented by the following cathodic and anodic half-reactions during charging:

On the negative electrode

$$
4 \mathrm{Al}_{2} \mathrm{Cl}_{7}^{-}+3 \mathrm{e}^{-} \leftrightarrow 7 \mathrm{AlCl}_{4}^{-}+\mathrm{Al}
$$

On the positive electrode

$$
x \mathrm{C}+\mathrm{AlCl}_{4}^{-} \leftrightarrow \mathrm{C}_{x}\left(\mathrm{AlCl}_{4}^{-}\right)+\mathrm{e}^{-}
$$

The chloroaluminate ionic liquid anolyte used in AGDIBs is defined as a mixture of aluminum chloride and other chlorides countered by a bulky organic cation, such as 1-ethyl-3methylimidazolium chloride (EMIM) or 1-butyl-3-methylimidazolium chloride (BMIM). As a result of the acid-base reaction between $\mathrm{AlCl}_{3}$ (Lewis acid) and $\mathrm{Cl}^{-}$(Lewis base), the solid mixture liquefies at room temperature, forming $\mathrm{AlCl}_{4}{ }^{-}$ anions that are charge-balanced with asymmetric organic cations, such as $\mathrm{EMIM}^{+}$. The chloroaluminate ionic liquid with an excess of $\mathrm{AlCl}_{3}$ over $\mathrm{EMIMCl}$ is composed of both $\mathrm{AlCl}_{4}^{-}$and $\mathrm{Al}_{2} \mathrm{Cl}_{7}^{-}$ions. Importantly, only $\mathrm{Al}_{2} \mathrm{Cl}_{7}^{-}$ions enable the electroplating of aluminum, which, therefore, occurs only in acidic chloroaluminate melts (i.e., an excess of $\mathrm{AlCl}_{3}$ ). ${ }^{31-40}$ Consequently, the specific charge storage capacity of the acidic melt is a function of the concentration of $\mathrm{Al}_{2} \mathrm{Cl}_{7}^{-}$ions in the ionic liquid. Electroplating, and consequently the charging process, stops when no $\mathrm{Al}_{2} \mathrm{Cl}_{7}^{-}$ions remain in the ionic liquid, at which point the melt becomes neutral $\left(\mathrm{AlCl}_{3}: \mathrm{EMIMCl}=1\right)$. The highest molar ratio $(r)$ of $\mathrm{AlCl}_{3}$ and EMIMCl that forms an ionic liquid is ca. $2: 1 . \mathrm{AlCl}_{3}$ does not dissolve in the chloroaluminate melts at higher molar ratios. In this context, we note that the mechanism of AGDIBs is substantially different from the operation of "rocking-chair" metal-ion batteries: there is no unidirectional flow of $\mathrm{Al}^{3+}$ ions from the cathode to the anode and vice versa. In fact, the $\mathrm{Al}$ species are depleted from the chloroaluminate ionic liquid during the charge of AGDIBs and are being consumed by both electrodes (Figure 1a). Notably, the electrochemistry of AGDIBs is not restricted to $\mathrm{AlCl}_{3} / \mathrm{EMIMCl}$ ionic liquids. Other possible ionic melts have also been recently tested in AGDIBs, such as $\mathrm{AlCl}_{3} / 1$-methyl-3-propylimidazolium chloride ( $\mathrm{MPIMCl}),{ }^{41} \mathrm{AlCl}_{3}$ /benzyltriethylammonium chloride (TEBACl), ${ }^{42} \mathrm{AlCl}_{3}$ /1,2-dimethyl-3-propylimidazolium chloroaluminate (DMPICl), ${ }^{43} \mathrm{AlCl}_{3} / \mathrm{NaCl}^{44}$ and $\mathrm{AlCl}_{3} / \mathrm{LiCl} /$ $\mathrm{KCl}^{45}$ or $\mathrm{AlCl}_{3} /$ urea/EMIMCl, ${ }^{46} \mathrm{AlCl}_{3} /$ urea, ${ }^{47-49}$ and $\mathrm{AlCl}_{3} /$ $\mathrm{Et}_{3} \mathrm{NHCl}^{50,51}$

Figure $1 \mathrm{~b}$ illustrates the impact of acidity $(r)$ on the charge storage capacity of the chloroaluminate ionic liquid anolyte. The

Received: December 28, 2019

Accepted: January 9, 2020

Published: January 22, 2020 

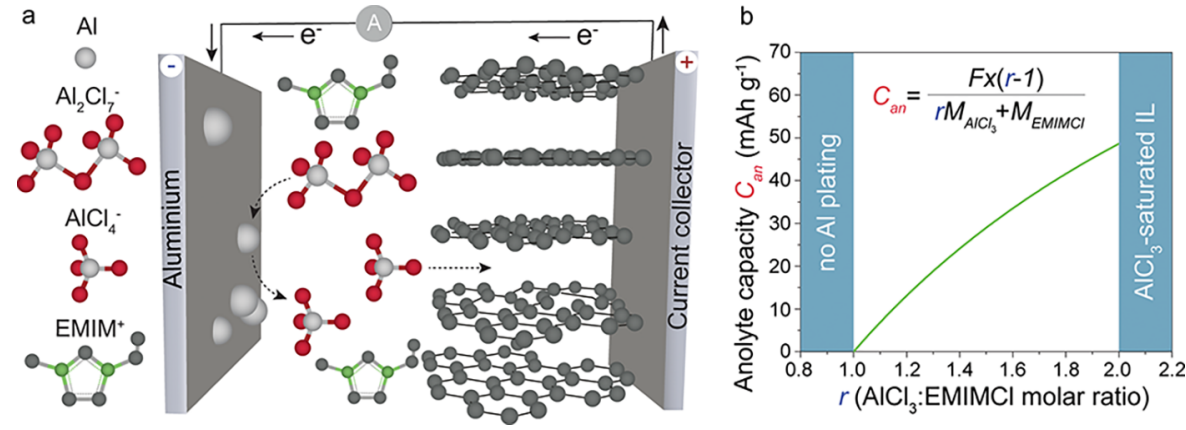

Figure 1. (a) Schematic of the charging process of aluminum GDIBs. (b) Charge storage capacity of the chloroaluminate ionic liquid anolyte $\left(\mathrm{AlCl}_{3}\right.$ : EMIMCl) versus its acidity $(r)$. The curve is computed from eq 1 .
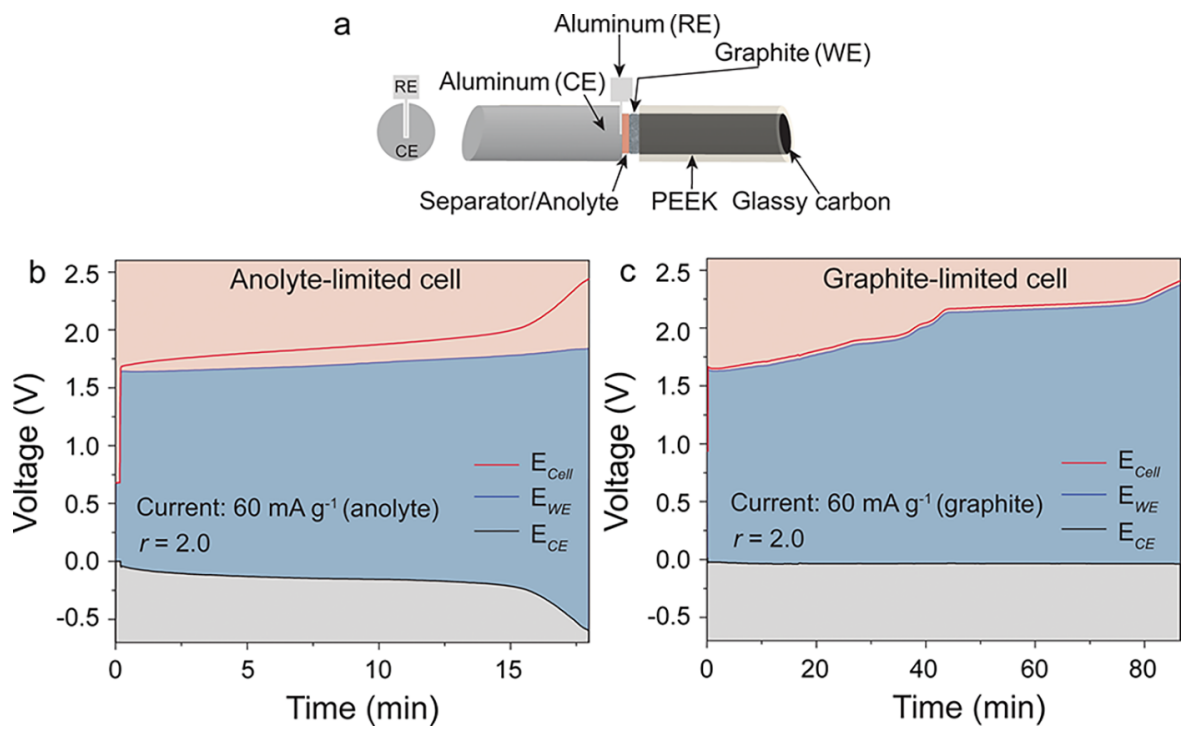

Figure 2. (a) Three-electrode cell configuration of the AGDIBs (the location of the reference electrode is shown on the left). (b and c) Galvanostatic charge curves for the chloroaluminate ionic liquid $(r=2)$ anolyte $\left(E_{\mathrm{CE}}\right)$, graphite $\left(E_{\mathrm{WE}}\right)$, and full cell $\left(E_{\mathrm{Cell}}\right)$ measured versus the $\mathrm{Al}$ foil reference electrode in anolyte-limited $(\mathrm{b})$ and graphite-limited $(\mathrm{c})$ cell configurations. The cells were charged at room temperature with a current density of $60 \mathrm{~mA} \mathrm{~g}^{-1}$ and an upper voltage limit of $2.5 \mathrm{~V} \mathrm{vs} \mathrm{Al}^{3+} / \mathrm{Al}$. In the case of the graphite-limited cell configuration, a 5-fold excess of the anolyte over graphite was used.

theoretical capacity of the ionic liquid $\left(C_{a n}\right)$ as an anolyte, considering its whole mass/volume, can be calculated as follows:

\section{Gravimetric}

$$
C_{\text {an }}=\frac{F x(r-1)}{r M_{\mathrm{AlCl}_{3}}+M_{\mathrm{ACl}}}\left(\mathrm{mAhg}^{-1}\right)
$$

\section{Volumetric}

$$
C_{\mathrm{an}}=\frac{F x(r-1) \rho}{r M_{\mathrm{AlCl}_{3}}+M_{\mathrm{ACl}}}\left(\mathrm{mAh} \mathrm{mL}^{-1}\right)
$$

where $F=26.8 \times 10^{3} \mathrm{mAh} \mathrm{mol}^{-1}$ (the Faraday constant), and $x=\frac{3}{4}$ (number of electrons used to reduce $1 \mathrm{~mol}$ of the $\mathrm{Al}_{2} \mathrm{Cl}_{7}^{-}$ ions); $M_{\mathrm{AlCl}_{3}}$ is the molar mass of $\mathrm{AlCl}_{3}$ in $\mathrm{g} \mathrm{mol}^{-1}, \mathrm{M}_{\mathrm{ACl}}$ the molar mass of the $\mathrm{Cl}^{-}$source (for example, EMIMCl) in $\mathrm{g}$ $\mathrm{mol}^{-1}, r$ the $\mathrm{AlCl}_{3}: \mathrm{ACl}$ molar ratio, and $\rho$ the density of the chloroaluminate-based anolyte in $\mathrm{g} \mathrm{mL}^{-1}$.

The theoretical gravimetric charge storage capacities of $\mathrm{AlCl}_{3}: \mathrm{EMIMCl}$ ionic liquids equal, for instance, to $48 \mathrm{mAh}$ $\mathrm{g}^{-1}$ and $19 \mathrm{mAh} \mathrm{g}^{-1}$ for $r=2$ and $r=1.3$, respectively. These capacities determine and limit the overall energy density of AGDIBs, as previously pointed by us ${ }^{7,27}$ and others. ${ }^{52-59}$ To the best of our knowledge, it had not been verified whether these capacities are achievable experimentally, i.e. whether $\mathrm{Al}_{2} \mathrm{Cl}_{7}^{-}$ ions can be fully depleted for $\mathrm{Al}$ electroplating at practically relevant experimental conditions. For this, the anolyte-limited cell must be assembled, that is, the cell with the significant excess of graphite cathode. On the contrary, the commonly reported AGDIB tests employ an up to 10-fold excess of anolyte (or even higher). We note that such a 10 -fold anolyte access can be recalculated into an impractical overall charge-storage capacity of the cell $\left(<5 \mathrm{mAh} \mathrm{g}^{-1}\right)$. In the anolyte-limited cell, depletion of $\mathrm{Al}_{2} \mathrm{Cl}_{7}^{-}$ions $r$ will eventually cause a drop in the potential at the negative electrode of the battery. It is thus also important to conduct tests in a three-electrode configuration in order to differentiate between changes in the potentials originating at positive and negative electrodes.

Following these considerations, we prepared an anolytelimited full cell, in which an excess of graphite flakes was used in combination with the anolyte, i.e. having roughly an order of magnitude higher cathodic capacity in comparison to that needed to match the theoretical charge storage capacity of the anolyte. AGDIBs were assembled using a three-electrode cell 

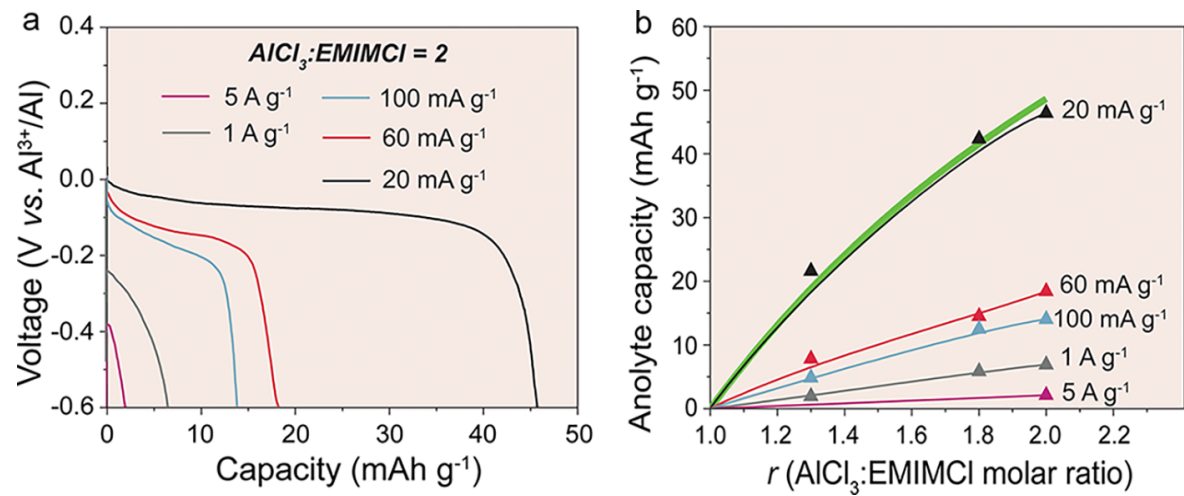

Figure 3. (a) Galvanostatic Al plating (discharge) curves of the chloroaluminate ionic liquid anolyte with $r=2.0$ measured at different current densities in combination with graphite as the working electrode and $\mathrm{Al}$ foil as the reference electrode. (b) Charge storage capacities of the chloroaluminate ionic liquid anolyte with $r=1.3,1.8$, and 2.0 measured at different current densities. The green line shows the theoretical charge storage capacity of the anolyte computed from eq 1.

composed of a glassy carbon current collector, graphite flake cathode, $\mathrm{Al}$ foil reference electrode, separator impregnated with chloroaluminate ionic liquid anolyte, and Al foil current collector (Figure 2a). The cells were cycled between 2.5 and $0.1 \mathrm{~V}$ vs $\mathrm{Al}^{3+} / \mathrm{Al}$. An example of the electrochemical measurement at a current density of $60 \mathrm{~mA} \mathrm{~g}^{-1}$ is shown in Figure $2 \mathrm{~b}$ using a chloroaluminate ionic liquid with a molar ratio of 2.0. In these measurements, the simultaneous acquisition of the potential profiles of both positive and negative electrodes was recorded, in addition to that of the full cell.

As follows from Figure $2 b$, the voltage profile at the negative electrode $\left(E_{\mathrm{CE}}\right)$ remains relatively stable during charging for 15 $\mathrm{min}$, with a small overpotential of up to $200 \mathrm{mV}$. However, upon further charging, this voltage drops sharply when the $\mathrm{Al}$ plating process ends. The plating termination is also reflected in the sharp increase in the overall potential of the cell of up to $2.5 \mathrm{~V}$ vs $\mathrm{Al}^{3+} / \mathrm{Al}$. The potential at the positive electrode $\left(E_{\mathrm{WE}}\right)$, however, is relatively stable for the full charging cycle. In contrast to the anolyte-limited cell, the voltage profile at the negative electrode $\left(E_{\mathrm{CE}}\right)$ for the graphite-limited cell is very stable during the entire charge, with a minimal overpotential of $<50 \mathrm{mV}$ (Figure 2c). As indicated above, the graphite-limited cell configuration is used for the assessment of the charge storage capacity of graphite in the majority of research studies on AGDIBs.

Using the ionic liquid formulations with $r=1.3-2.0$, we performed rate capability measurements of anolyte-limited full cells at different current densities ranging from $5 \mathrm{~A} \mathrm{~g}^{-1}$ to $20 \mathrm{~mA}$ $\mathrm{g}^{-1}$. Figure 3a presents the galvanostatic curves of the anolyte with $r=2$ during charging (see Figure S1 for details). The electrochemical data for $r=1.3$ and 1.8 are shown in the Supporting Information (Figures S2 and S3). Figure 3b summarizes these results in terms of the obtained charge storage capacities at different current densities. The results reveal two major points. First, a more acidic anolyte yields, as expected, a higher anolyte capacity. For instance, the charge storage capacity of the most commonly used anolyte with $r=1.3$ is ca. $21 \mathrm{mAh} \mathrm{g}^{-1}$ at $20 \mathrm{~mA} \mathrm{~g}^{-1}$. In contrast, the anolyte with the highest acidity $(r=2.0)$ possesses a capacity of ca. $46 \mathrm{mAh} \mathrm{g}^{-1}$. These results point to the fact that the highest energy density of the AGDIBs can be obtained using a 2.0 molar ratio, and therefore, future works on AGDIBs should be focused on the most acidic formulations. Second, the charge storage capacity of the anolyte is highly dependent on the applied current density. For instance, at a high current density of $1 \mathrm{~A} \mathrm{~g}^{-1}$, minimal charge storage capacities are obtained (ca. $10-14 \%$ from theoretical values). The latter point is reflected in the pronounced deviation of the voltage profiles at the negative electrode at high current densities (Figures $3 \mathrm{a}$ and $\mathrm{S} 1-\mathrm{S} 3$ ). Conversely, minimal polarization is observed at the graphite positive electrode. These results indicate that the frequent statements regarding the high power density of AGDIBs need to be taken with care. Specifically, we note that at high current densities a significant drop in the energy density of AGDIBs is expected and originated from the rate capability limitations of the chloroaluminate ionic liquid anolyte when its acidity (concentration of $\mathrm{Al}_{2} \mathrm{Cl}_{7}^{-}$) is drastically reduced. In fact, our observations show that the charge storage capacities of the anolyte significantly deviate from the theoretical value at charge current densities greater than 20 $\mathrm{mA} \mathrm{g}^{-1}$.

In conclusion, we reiterate that commonly reported tests of AGDIBs employ large excess of ionic liquid anolyte (cathodelimited cells) and, despite nominally dealing with full cells, do not provide correct and practically relevant information on achievable energy and power densities, as well as cycling stability, energy and Coulombic efficiencies of these batteries. At best, such tests yield the theoretical capacities and other characteristics of the cathode material only, similar to, for instance, Li-ion half-cell tests of novel cathodes (with thick $\mathrm{Li}$ foil as a counter electrode). We further note that ionic liquids used in AGDIBs are not just electrolytes (ion-conductors) but represent an electrochemically active, capacity- and rate-limiting battery component. It is also apparent that future work should focus on finding ways of minimizing the amount of this anolyte toward the capacity-matched quantity, ideally with just ca. $10 \%$ of the excess anolyte, without sacrificing the power density and cyclability of the battery. Most likely, a successful solution to this problem will invoke a radically new battery design, vastly different from that employed in commercial Li-ion batteries and nearly all tests of new battery materials. All these advancements will need to come at low capital costs in order to retain the overall cost-competitiveness that is commonly attributed to AGDIBs (based on low costs of electrochemically active constituents). Similar considerations apply also to other nonrocking-chair batteries, such as magnesium-sodium and magnesium-lithium dual-ion batteries.

Kostiantyn V. Kravchyk @ orcid.org/0000-0001-6149-193X

Carlotta Seno

Maksym V. Kovalenko @ orcid.org/0000-0002-6396-8938 


\section{ASSOCIATED CONTENT}

\section{(s) Supporting Information}

The Supporting Information is available free of charge at https://pubs.acs.org/doi/10.1021/acsenergylett.9b02832.

Additional electrochemical data (PDF)

\section{AUTHOR INFORMATION}

Complete contact information is available at: https://pubs.acs.org/10.1021/acsenergylett.9b02832

\section{Notes}

Views expressed in this Viewpoint are those of the authors and not necessarily the views of the ACS.

The authors declare no competing financial interest.

\section{ACKNOWLEDGMENTS}

This research is part of the activities of SCCER HaE, which is financially supported by Innosuisse - Swiss Innovation Agency.

\section{REFERENCES}

(1) Grosjean, C.; Miranda, P. H.; Perrin, M.; Poggi, P. Assessment of world lithium resources and consequences of their geographic distribution on the expected development of the electric vehicle industry. Renewable Sustainable Energy Rev. 2012, 16 (3), 1735-1744.

(2) Muldoon, J.; Bucur, C. B.; Gregory, T. Quest for nonaqueous multivalent secondary batteries: Magnesium and beyond. Chem. Rev. 2014, 114 (23), 11683-11720.

(3) Nitta, N.; Wu, F.; Lee, J. T.; Yushin, G. Li-ion battery materials: present and future. Mater. Today 2015, 18 (5), 252-264.

(4) Schoetz, T.; de Leon, C. P.; Ueda, M.; Bund, A. Perspective-state of the art of rechargeable aluminum batteries in non-aqueous systems. J. Electrochem. Soc. 2017, 164 (14), A3499-A3502.

(5) Elia, G. A.; Marquardt, K.; Hoeppner, K.; Fantini, S.; Lin, R.; Knipping, E.; Peters, W.; Drillet, J.-F.; Passerini, S.; Hahn, R. An overview and future perspectives of aluminum batteries. Adv. Mater. 2016, 28 (35), 7564-7579.

(6) Lin, M.-C.; Gong, M.; Lu, B.; Wu, Y.; Wang, D.-Y.; Guan, M.; Angell, M.; Chen, C.; Yang, J.; Hwang, B.-J.; Dai, H. An ultrafast rechargeable aluminium-ion battery. Nature 2015, 520, 324.

(7) Kravchyk, K. V.; Wang, S.; Piveteau, L.; Kovalenko, M. V. Efficient aluminum chloride-natural graphite battery. Chem. Mater. 2017, 29 (10), 4484-4492.

(8) Wang, D.-Y.; Wei, C.-Y.; Lin, M.-C.; Pan, C.-J.; Chou, H.-L.; Chen, H.-A.; Gong, M.; Wu, Y.; Yuan, C.; Angell, M.; Hsieh, Y.-J.; Chen, Y.H.; Wen, C.-Y.; Chen, C.-W.; Hwang, B.-J.; Chen, C.-C.; Dai, H. Advanced rechargeable aluminium ion battery with a high-quality natural graphite cathode. Nat. Commun. 2017, 8, 14283.

(9) Wu, F.; Yang, H.; Bai, Y.; Wu, C. Paving the path toward reliable cathode materials for aluminum-ion batteries. Adv. Mater. 2019, 31 (16), 1806510.

(10) Muñoz-Torrero, D.; Palma, J.; Marcilla, R.; Ventosa, E. A critical perspective on rechargeable Al-ion battery technology. Dalton Trans. 2019, 48 (27), 9906-9911.

(11) Muñoz-Torrero, D.; Anderson, M.; Palma, J.; Marcilla, R.; Ventosa, E. Unexpected contribution of current collector to the cost of rechargeable Al-ion batteries. ChemElectroChem 2019, 6 (10), 27662770.

(12) Xu, J. H.; Turney, D. E.; Jadhav, A. L.; Messinger, R. J. Effects of graphite structure and ion transport on the electrochemical properties of rechargeable aluminum-graphite batteries. ACS Appl. Energy Mater. 2019, 2 (11), 7799-7810.

(13) Zhang, E.; Wang, J.; Wang, B.; Yu, X.; Yang, H.; Lu, B. Unzipped carbon nanotubes for aluminum battery. Energy Storage Mater. 2019, 23, 72-78.

(14) Hu, Y.; Debnath, S.; Hu, H.; Luo, B.; Zhu, X.; Wang, S.; Hankel, M.; Searles, D. J.; Wang, L. Unlocking the potential of commercial carbon nanofibers as free-standing positive electrodes for flexible aluminum ion batteries. J. Mater. Chem. A 2019, 7 (25), 15123-15130.

(15) Liu, C.; Liu, Z.; Li, Q.; Niu, H.; Wang, C.; Wang, Z.; Gao, B. Binder-free ultrasonicated graphite flakes@carbon fiber cloth cathode for rechargeable aluminum-ion battery. J. Power Sources 2019, 438, 226950.

(16) Bhauriyal, P.; Bhattacharyya, G.; Rawat, K. S.; Pathak, B. Graphene/hBN heterostructures as high-capacity cathodes with high voltage for next-generation aluminum batteries. J. Phys. Chem. C 2019, 123 (7), 3959-3967.

(17) Liu, C.; Liu, Z.; Niu, H.; Wang, C.; Wang, Z.; Gao, B.; Liu, J.; Taylor, M. Preparation and in-situ Raman characterization of binderfree u-GF@CFC cathode for rechargeable aluminum-ion battery. MethodsX 2019, 6, 2374-2383.

(18) Song, W.-L.; Li, S.; Zhang, G.; Tu, J.; Chen, H.-S.; Jiao, S. Cellulose-derived flake graphite as positive electrodes for Al-ion batteries. Sustainable Energy Fuels 2019, 3 (12), 3561-3568.

(19) Dong, X.; Xu, H.; Chen, H.; Wang, L.; Wang, J.; Fang, W.; Chen, C.; Salman, M.; Xu, Z.; Gao, C. Commercial expanded graphite as highperformance cathode for low-cost aluminum-ion battery. Carbon 2019, $148,134-140$.

(20) Huang, H.; Zhou, F.; Shi, X.; Qin, J.; Zhang, Z.; Bao, X.; Wu, Z.-S. Graphene aerogel derived compact films for ultrafast and high-capacity aluminum ion batteries. Energy Storage Mater. 2019, 23, 664-669.

(21) Shi, J.; Zhang, J.; Guo, J. Avoiding pitfalls in rechargeable aluminum batteries research. ACS Energy Lett. 2019, 4 (9), 2124-2129.

(22) Greco, G.; Tatchev, D.; Hoell, A.; Krumrey, M.; Raoux, S.; Hahn, R.; Elia, G. A. Influence of the electrode nano/microstructure on the electrochemical properties of graphite in aluminum batteries. J. Mater. Chem. A 2018, 6 (45), 22673-22680.

(23) Elia, G. A.; Ducros, J.-B.; Sotta, D.; Delhorbe, V.; Brun, A.; Marquardt, K.; Hahn, R. Polyacrylonitrile separator for high-performance aluminum batteries with improved interface stability. ACS Appl. Mater. Interfaces 2017, 9 (44), 38381-38389.

(24) Elia, G. A.; Hasa, I.; Greco, G.; Diemant, T.; Marquardt, K.; Hoeppner, K.; Behm, R. J.; Hoell, A.; Passerini, S.; Hahn, R. Insights into the reversibility of aluminum graphite batteries. J. Mater. Chem. A 2017, 5 (20), 9682-9690.

(25) Elia, G. A.; Kyeremateng, N. A.; Marquardt, K.; Hahn, R. An aluminum/graphite battery with ultra-high rate capability. Batteries Supercaps 2018, 2 (1), 83-90.

(26) Yang, H.; Li, H.; Li, J.; Sun, Z.; He, K.; Cheng, H.-M.; Li, F. The rechargeable aluminum battery: opportunities and challenges. Angew. Chem., Int. Ed. 2019, 58 (35), 11978-11996.

(27) Kravchyk, K. V.; Kovalenko, M. V. Rechargeable dual-ion batteries with graphite as a cathode: key challenges and opportunities. Adv. Energy Mater. 2019, 9 (35), 1901749.

(28) Wang, S.; Kravchyk, K. V.; Krumeich, F.; Kovalenko, M. V. Kish graphite flakes as a cathode material for an aluminum chloridegraphite battery. ACS Appl. Mater. Interfaces 2017, 9 (34), 2847828485.

(29) Wang, S.; Kravchyk, K. V.; Filippin, A. N.; Müller, U.; Tiwari, A. N.; Buecheler, S.; Bodnarchuk, M. I.; Kovalenko, M. V. Aluminum chloride-graphite batteries with flexible current collectors prepared from earth-abundant elements. Adv. Sci. 2018, 5, 1700712.

(30) Chen, H.; Xu, H.; Wang, S.; Huang, T.; Xi, J.; Cai, S.; Guo, F.; Xu, Z.; Gao, W.; Gao, C. Ultrafast all-climate aluminum-graphene battery with quarter-million cycle life. Sci. Adv. 2017, 3 (12), eaao7233.

(31) Lai, P. K.; Skyllas-Kazacos, M. Aluminium deposition and dissolution in aluminium chloride $-\mathrm{n}$-butylpyridinium chloride melts. Electrochim. Acta 1987, 32 (10), 1443-1449.

(32) Chao-Cheng, Y. Electrodeposition of aluminum in molten $\mathrm{AlCl}_{3-}$ n-butylpyridinium chloride electrolyte. Mater. Chem. Phys. 1994, 37 (4), 355-361.

(33) Zhao, Y.; VanderNoot, T. J. Electrodeposition of aluminium from nonaqueous organic electrolytic systems and room temperature molten salts. Electrochim. Acta 1997, 42 (1), 3-13.

(34) Zein El Abedin, S.; Moustafa, E. M.; Hempelmann, R.; Natter, H.; Endres, F. Electrodeposition of nano- and microcrystalline 
aluminium in three different air and water stable ionic liquids. ChemPhysChem 2006, 7 (7), 1535-1543.

(35) Jiang, T.; Chollier Brym, M. J.; Dubé, G.; Lasia, A.; Brisard, G. M. Electrodeposition of aluminium from ionic liquids: Part I-electrodeposition and surface morphology of aluminium from aluminium chloride $\left(\mathrm{AlCl}_{3}\right)$-1-ethyl-3-methylimidazolium chloride $([\mathrm{EMIm}] \mathrm{Cl})$ ionic liquids. Surf. Coat. Technol. 2006, 201 (1-2), 1-9.

(36) Jiang, T.; Chollier Brym, M. J.; Dubé, G.; Lasia, A.; Brisard, G. M. Electrodeposition of aluminium from ionic liquids: Part II - studies on the electrodeposition of aluminum from aluminum chloride $\left(\mathrm{AICl}_{3}\right)$ trimethylphenylammonium chloride (TMPAC) ionic liquids. Surf. Coat. Technol. 2006, 201 (1-2), 10-18.

(37) Abood, H. M. A.; Abbott, A. P.; Ballantyne, A. D.; Ryder, K. S. Do all ionic liquids need organic cations? Characterisation of $\left[\mathrm{AlCl}_{2}\right.$. nAmide $]^{+} \mathrm{AlCl}_{4}{ }^{-}$and comparison with imidazolium based systems. Chem. Commun. 2011, 47 (12), 3523-3525.

(38) Abbott, A. P.; Harris, R. C.; Hsieh, Y.-T.; Ryder, K. S.; Sun, I. W. Aluminium electrodeposition under ambient conditions. Phys. Chem. Chem. Phys. 2014, 16 (28), 14675-14681.

(39) Bakkar, A.; Neubert, V. A new method for practical electrodeposition of aluminium from ionic liquids. Electrochem. Commun. 2015, 51, 113-116.

(40) Fang, Y.; Yoshii, K.; Jiang, X.; Sun, X.-G.; Tsuda, T.; Mehio, N.; Dai, S. An $\mathrm{AlCl}_{3}$ based ionic liquid with a neutral substituted pyridine ligand for electrochemical deposition of aluminum. Electrochim. Acta 2015, 160, 82-88.

(41) Yang, C.; Wang, S.; Zhang, X.; Zhang, Q.; Ma, W.; Yu, S.; Sun, G. Substituent effect of imidazolium ionic liquid: a potential strategy for high coulombic efficiency Al battery. J. Phys. Chem. C 2019, 123 (18), $11522-11528$.

(42) Xu, C.; Li, J.; Chen, H.; Zhang, J. Benzyltriethylammonium chloride electrolyte for high-performance Al-ion batteries. ChemNanoMat 2019, 5 (11), 1367-1372.

(43) Lv, Z.; Han, M.; Sun, J.; Hou, L.; Chen, H.; Li, Y.; Lin, M.-C. A high discharge voltage dual-ion rechargeable battery using pure $\left(\mathrm{DMPI}^{+}\right)\left(\mathrm{AlCl}_{4}^{-}\right)$ionic liquid electrolyte. J. Power Sources 2019, 418, 233-240.

(44) Song, Y.; Jiao, S.; Tu, J.; Wang, J.; Liu, Y.; Jiao, H.; Mao, X.; Guo, Z.; Fray, D. J. A long-life rechargeable $\mathrm{Al}$ ion battery based on molten salts. J. Mater. Chem. A 2017, 5 (3), 1282-1291.

(45) Wang, J.; Zhang, X.; Chu, W.; Liu, S.; Yu, H. A sub-100 ${ }^{\circ} \mathrm{C}$ aluminum ion battery based on a ternary inorganic molten salt. Chem. Commun. 2019, 55 (15), 2138-2141.

(46) Li, J.; Tu, J.; Jiao, H.; Wang, C.; Jiao, S. Ternary $\mathrm{AlCl}_{3}$-urea[EMIm] Cl ionic liquid electrolyte for rechargeable aluminum-ion batteries. J. Electrochem. Soc. 2017, 164 (13), A3093-A3100.

(47) Jiao, H.; Wang, C.; Tu, J.; Tian, D.; Jiao, S. A rechargeable Al-ion battery: $\mathrm{Al} /$ molten $\mathrm{AlCl}_{3}$-urea/graphite. Chem. Commun. 2017, 53 (15), 2331-2334.

(48) Angell, M.; Pan, C.-J.; Rong, Y.; Yuan, C.; Lin, M.-C.; Hwang, B.J.; Dai, H. High coulombic efficiency aluminum-ion battery using an $\mathrm{AlCl}_{3}$-urea ionic liquid analog electrolyte. Proc. Natl. Acad. Sci. U. S. A. 2017, 114 (5), 834-839.

(49) Ng, K. L.; Malik, M.; Buch, E.; Glossmann, T.; Hintennach, A.; Azimi, G. A low-cost rechargeable aluminum/natural graphite battery utilizing urea-based ionic liquid analog. Electrochim. Acta 2019, 327, 135031 .

(50) Gan, F.; Chen, K.; Li, N.; Wang, Y.; Shuai, Y.; He, X. Low cost ionic liquid electrolytes for rechargeable aluminum/graphite batteries. Ionics 2019, 25, 4243-4249.

(51) Xu, H.; Bai, T.; Chen, H.; Guo, F.; Xi, J.; Huang, T.; Cai, S.; Chu, X.; Ling, J.; Gao, W.; Xu, Z.; Gao, C. Low-cost $\mathrm{AlCl}_{3} / \mathrm{Et}_{3} \mathrm{NHCl}$ electrolyte for high-performance aluminum-ion battery. Energy Storage Mater. 2019, 17, 38-45.

(52) Zhao, X.; Zhao-Karger, Z.; Fichtner, M.; Shen, X. Halide-based materials and chemistries for rechargeable batteries. Angew. Chem., Int. Ed. 2020, DOI: 10.1002 /anie.201902842.

(53) Bitenc, J.; Lindahl, N.; Vizintin, A.; Abdelhamid, M. E.; Dominko, R.; Johansson, P. Concept and electrochemical mechanism of an $\mathrm{Al}$ metal anode - organic cathode battery. Energy Storage Mater. 2020, 24, 379-383.

(54) Leisegang, T.; Meutzner, F.; Zschornak, M.; Münchgesang, W.; Schmid, R.; Nestler, T.; Eremin, R. A.; Kabanov, A. A.; Blatov, V. A.; Meyer, D. C. The Aluminum-ion battery: A sustainable and seminal concept? Front. Chem. 2019, 7, 268.

(55) Sui, Y.; Liu, C.; Masse, R. C.; Neale, Z. G.; Atif, M.; AlSalhi, M.; Cao, G. Dual-ion batteries: The emerging alternative rechargeable batteries. Energy Storage Mater. 2019, DOI: 10.1016/ j.ensm.2019.11.003.

(56) Muñoz-Torrero, D.; Palma, J.; Marcilla, R.; Ventosa, E. A critical perspective on rechargeable Al-ion battery technology. Dalton Transactions 2019, 48 (27), 9906-9911.

(57) Zhao, H.; Xu, J.; Yin, D.; Du, Y. Electrolytes for batteries with earth-abundant metal anodes. Chem. - Eur. J. 2018, 24 (69), 1822018234 .

(58) Chen, C.-Y.; Tsuda, T.; Kuwabata, S.; Hussey, C. L. Rechargeable aluminum batteries utilizing a chloroaluminate inorganic ionic liquid electrolyte. Chem. Commun. 2018, 54 (33), 4164-4167.

(59) Liu, Z.; Wang, J.; Ding, H.; Chen, S.; Yu, X.; Lu, B. Carbon nanoscrolls for aluminum battery. ACS Nano 2018, 12 (8), 8456-8466. 